\title{
Karakterisasi Kematangan Buah Kopi Berdasarkan Warna Kulit Kopi Menggunakan Histogram dan Momen Warna
}

\author{
Hendri Syahputra $^{2}$, Fitri Arnia ${ }^{1^{*}}$ dan Khairul Munadi ${ }^{1}$ \\ ${ }^{1}$ Jurusan Teknik Elektro dan Komputer, Fakultas Teknik, Universitas Syiah Kuala \\ ${ }^{2}$ Program Studi Magister Teknik Elektro, Fakultas Teknik, Universitas Syiah Kuala \\ *Corresponding author, e-mail: f.arnia@unsyiah.ac.id
}

\begin{abstract}
Abstrak - Secara tradisional, tingkat kematangan buah kopi ditentukan dari warna kulitnya yang dikelompokan secara manual. Cara ini menghasilkan pengelompokan warna yang kurang konsisten, sehingga diperlukan sebuah metode otomatis pengelompokan buah kopi berdasarkan warna dari tingkat kematangannya. Penelitian ini memaparkan hasil karakterisasi kematangan buah kopi arabika menggunakan dua fitur warna citra, yaitu histogram dan momen warna. Karakterisasi kematangan dibagi menjadi empat kelompok: hijau untuk kopi muda, hijau kekuningan untuk kopi setengah masak, merah untuk kopi masak, dan merah tua untuk kopi tua. Tujuan penelitian ini adalah menentukan fitur warna yang dapat mewakili karakter kematangan buah kopi dengan melakukan simulasi komputer untuk mengekstrak dan menghitung nilai statistik dari histogram warna dan nilai momen warna dari empat kelompok buah kopi. Hasil penelitian menggunakan 200 citra kopi menunjukkan bahwa nilai statistik dari histogram warna lebih menggambarkan karakter kematangan buah kopi, dibandingkan dengan momen warna. Nilai kurtosis dari histogram hue memiliki nilai berbeda untuk setiap kategori kematangan buah kopi: kopi muda memiliki nilai kurtosis 17.2-28.3, kopi setengah masak 29.2-31.4, kopi masak 32.7-83.5dan kopi tua lebih dari 84.2.
\end{abstract}

Kata Kunci : kurtosis histogram warna, momen warna, pengolahan citra.

\begin{abstract}
Conventionally, the coffee maturity level is determined by observing the fruit colour, and it is done manually. This approach may result in inconsistency in colour classification. Thus, an automatic colour classification method based on colour of coffee maturity level is required. This paper presents the characterization of coffee maturity level based on two colour features: colour histogram and colour moment. Characterization of coffee maturity level was grouped into four class: green for unripe coffee, greenish-yellow for half ripe coffee, red for ripe coffee, and dark red for too ripe coffee. The purpose of the research is to determine the colour features that can characterize the coffee maturity level based on computer simulation in extracting and calculating the statistical values of the colour histogram and colour moments. It turned out from 200 coffee images that the statistical values of colour histogram are more suitable for characterising the coffee maturity. The kurtosis values of hue histogram for each maturity level of coffee were different: kurtosis value of unripe coffee was 17.2-28.3, those of half ripe coffee, ripe coffee and too ripe coffee were 29.2-31.4, $32.7-83.5$, and more than 84.2 respectively.
\end{abstract}

Keywords : colour histogram kurtosis, colour moment, image processing.

\section{Pendahuluan}

Kopi (Coffea) merupakan sejenis minuman yang berasal dari proses pengolahan dan ekstraksi biji tanaman buah, jenis tanaman buah berbentuk pohon yang termasuk dalam famili Rubiaceae dan genus coffea. Pengolahan kopi sangat berperan penting dalam menentukan cita rasa dan kualitas kopi [1]. Saat ini peningkatan produksi kopi di Indonesia masih terhambat oleh rendahnya mutu buah kopi yang dihasilkan sehingga mempengaruhi pengembangan produksi akhir kopi. Pengujian mutu fisik, selama ini masih menggunakan cara-cara tradisional. Cara-cara seperti ini sangat lambat dan menyebabkan bias yang sangat tinggi [2].

Ada dua cara pemanenan buah kopi yang umum dilakukan secara tradisional yaitu: pemanenan selektif pilih merah dan pemanenan racutan/rampasan yaitu pemetikan terhadap semua buah kopi baik yang masih hijau maupun yang merah dan biasanya dilakukan pada pemanenan akhir. Untuk mutu kopi yang baik pemanenan selektif sangat dianjurkan. Sedangkan pemanenan racutan/rampasan ini dilakukan melalui pemilihan buah kopi berwarna hijau tua yang belum merah secara satu persatu memerlukan proses yang 
cukup lama dalam proses pemanenan, sehingga hasil panen racutan/rampasan menyebabkan mutu kualitas buah kopi rendah. Proses pemilihan buah kopi merupakan salah satu tahapan yang penting, namun saat ini masih sedikit data tentang bagaimana proses pemilihan buah kopi yang tepat untuk menghasilkan produk kopi berkualitas.

Penelitian objek kopi berbasis citra digital saat ini telah banyak mengunakan teknologi sistem komputer dalam metode pengolahan berdasarkan deteksi citra. Teknik pengolahan citra mampu menganalisis penampilan suatu objek berdasarkan ukuran, warna dan bentuk. Teknik pengolahan citra telah dicoba untuk diaplikasikan pada deteksi cacat biji kopi, mengklasifikasi warna kematangan dan mutu biji kopi dan seterusnya [3-8].

Penelitian [3] menggunakan teknik pengolahan citra menggunakan metode klasifikasi deteksi cacat biji kopi berdasarkan pengolahan gambar citra digital untuk mendeteksi dan mengidentifikasi cacat biji kopi. Penelitian [4] menggunakan pengolahan citra digital untuk penentuan mutu biji kopi berdasarkan parameter tekstur (energy, entropy, contrast, homogeneity) dan warna ( $R$ mean, $G$ mean, dan $B$ mean) dengan metode algoritma jaringan saraf tiruan.

Penelitian [5] mengelompokkan biji kopi berdasarkana warna, bentuk dan tekstur dari 160 citra, dimana sebanyak 80 gambar digunakan sebagai data latih. Biji kopi dikelompokkan kedalam empat kelompok. Selanjutnya, Carillo mengklasifikasikan biji kopi menggunakan fitur warna, bentuk dan ukuran. Citra kopi diperoleh dengan kondisi pencahayaan yang terkendali, sedangkan pengelompokan biji kopi menggunakan jarak Mahalanobis [6].

Selanjutnya, metode sparse digunakan untuk menyeleksi variabel terbaik yang digunakan pada tahap klasifikasi biji kopi. Penelitian ini menganalisis citra infrared banyak spektrum (near-infrared hyperspectral image) dari biji kopi arabika dan robusta [7]. Penelitian [8] membahas sistem visi komputer untuk klasifikasi biji kopi hijau berdasarkan warna pada bidang CIE (Commission Internationale d'Eclairage) $\mathrm{L}^{*} \mathrm{a}^{*} \mathrm{~b}^{*}$. Artificial Neural Networks (ANN) digunakan sebagai model transformasi warna dari RGB ke CIE Lab, dan pengklasifikasi Bayes digunakan sebagai klasifikator biji kopi menjadi empat kelompok: warna keputihan, hijau tebu, hijau dan hijau kebiruan.

Penelitian [4-8] menggunakan teknik pengolahan citra untuk menentukan kualitas biji kopi, yaitu buah kopi yang telah mengalami proses pengeringan. Untuk memudahkan pengelompokan biji kopi, klasifikasi kematangan perlu dilakukan pada tahap pemilahan buah, yaitu tahap sebelum pengeringan kopi. Penelitian ini bertujuan untuk mendapatkan karakterisasi warna dari tingkat kematangan buah kopi. Kematangan kopi dikelompokkan menjadi empat kelas, yaitu kopi muda, kopi setengah masak, kopi masak dan kopi tua. Warna diekstraksi menggunakan histogram dan momen warna.

\section{Konversi Warna}

Selain bentuk dan tekstur, warna merupakan salah satu konten citra yang sering digunakan dalam klasifikasi dan temu kembali citra. Hasil ekstraksi konten citra disimpan dalam bentuk vektor yang dikenal dengan nama vektor fitur, atau fitur. Fitur warna yang digunakan pada penelitian ini adalah histogram dari komponen hue pada bidang warna HSV, dan momen warna dari bidang warna RGB.

Konversi warna RGB ke HSV diberikan oleh persamaan-persamaan (1) sampai (4) [9].

$$
\begin{aligned}
& r=\frac{R}{(R+G+B)}, \quad g=\frac{G}{(R+G+B)}, \quad b=\frac{B}{(R+G+B)} \\
& V=\max (r, g, b) \\
& S=\left\{\begin{array}{l}
0, \quad \text { jika } V=0 \\
1-\frac{\min (r, g, b)}{V}, \mathrm{~V}>0
\end{array}\right. \\
& H=\left\{\begin{aligned}
0, & \text { jika } S=0 \\
\frac{60 *(g-b)}{S * V}, \text { jika } V & =r \\
60 *\left[2+\frac{b-r}{S * V}\right], \text { jika } V & =g \\
60 *\left[4+\frac{r-g}{S * V}\right], \text { jika } V & =b
\end{aligned}\right.
\end{aligned}
$$

di sini, $r, g$ dan $b$ berturut-turut adalah nilai normalisasi komponen merah, hijau dan biru terhadap semua komponen warna; $V$ menotasikan 'value' dari bidang warna HSV, sedangkan $S$ dan $H$ berturut-turut menotasikan saturasi dan hue dari bidang warna HSV.

\subsection{Histogram Hue}

Histogram hue merupakan salah satu metode yang biasa digunakan pada pengolahan citra digital untuk merepresentasikan nilai fitur suatu warna. Histogram adalah grafik vertikal yang 
menggambarkan penyebaran nilai-nilai intensitas piksel dari suatu gambar atau bagian tertentu di dalam gambar berdasarkan format warna HSV/HSL/HSB. Dari sebuah histogram dapat diketahui frekuensi kemunculan nisbi dari intensitas pada gambar tersebut. Karena itu, histogram adalah alat bantu yang berharga dalam pekerjaan pengolahan gambar baik secara kualitatif maupun kuantitatif. Histogram hue pada dasarnya sama dengan histogram RGB bedanya pada histogram hue menggunakan nilai hue sebagai ganti dari RGB karena nilai hue menyatakan warna alami tanpa memperhatikan pencahayaan.

Nilai hue diperoleh dari proses konversi RGB ke HSV. Penggunaan nilai hue disini dimaksudkan untuk mendapatkan warna asli dari gambar tanpa adanya pengaruh dari intensitas cahaya. Sehingga data fitur warna yang dihasilkan akan lebih baik dan lebih akurat jika dibandingkan dengan menggunakan histogram RGB yang sangat peka terhadap pengaruh cahaya. Statistik histogram bertujuan untuk mendeskripsikan atau menggambarkan data, yang dalam hal ini adalah nilai komponen hue dari citra kopi. Empat besaran statistik, yaitu mean, variance, skewness dan kurtosis digunakan dalam penelitian ini [9].

\subsection{Momen warna}

Momen warna memberikan nilai yang dapat digunakan untuk membedakan warna. Momen warna menghasilkan tiga momen level rendah dari sebuah citra. Nilai-nilai tersebut adalah mean, simpangan baku, dan skewness. Ketiga nilai tersebut cukup efektif dalam merepresentasikan penyebaran atau distribusi warna dari sebuah citra digital. Nilai mean, simpangan baku dan skewness dapat dihitung untuk setiap komponen warna dengan menggunakan persamaan (5) s.d. (7) [10]

$$
\begin{gathered}
E_{i=} \sum_{j=1}^{N} \frac{1}{N} P_{i j} \\
\sigma_{i}=\sqrt{\left.\frac{1}{N} \sum_{j=1}^{N}\left(P_{i j}-E_{i}\right)^{2}\right)} \\
\mathrm{S}_{i}=\sqrt[3]{\left(\frac{1}{N} \sum_{j=1}^{N}\left(P_{i j}-E_{i}\right)^{3}\right)}
\end{gathered}
$$

di sini, $E$ adalah rata-rata nilai warna dalam gambar (Mean), $\sigma$ adalah simpangan baku $S$ adalah notasi ukuran derajat ketidaksimetrisan (Skewness), $\mathrm{N}$ adalah jumlah total piksel pada gambar, dan $\mathrm{P}_{\mathrm{ij}}=$ Nilai dari komponen warna ke- $\mathrm{i}$ pada piksel ke-j.

\section{Metode}

Penelitian ini bertujuan untuk menentukan karakter kematangan buah kopi berdasarkan nilai statistik histogram dan momen warna dari citra kopi.

\subsection{Bahan dan kondisi simulasi}

Data yang digunakan adalah citra buah kopi arabika yang terdiri dari empat kategori warna berdasarkan kematangannya, yaitu: kopi arabika muda, kopi arabika setengah masak, kopi arabika masak, dan kopi arabika tua (lihat Gambar 1). Pengkategorian kematangan kopi seperti yang terlihat pada Gambar 1 didasarkan kepada pengamatan petani kopi.

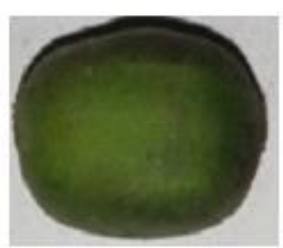

(a). arabika muda

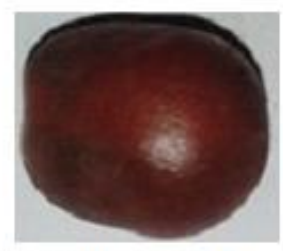

(c). arabika masak

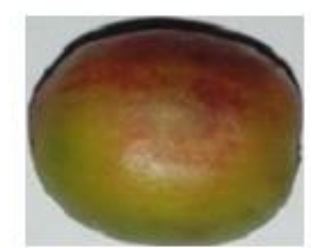

(b). arabika masak

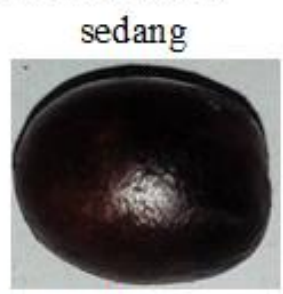

(d). arabika tua
Gambar 1. Empat macam tingkat kematangan buah kopi berdasarkan warna kulitnya

Simulasi dilakukan menggunakan dataset citra kopi yang diambil menggunakan kamera handphone 4,3 inci dengan resolusi $800 \times 480$ piksel dan kerapatan 230 ppi. Jumlah citra untuk setiap jenis citra kdapat dilihat pada Tabel 1.

\subsection{Alur simulasi}

Proses ekstraksi fitur citra buah kopi Arabika dilakukan sesuai dengan diagram pada Gambar 2. Terdapat dua jenis metode ekstraksi fitur yaitu histogram dan momen warna yang dilakukan secara terpisah. Citra asli merupakan citra dengan format RGB (red, green, blue). Kemudian citra warna tersebut di cropping, dan selanjutnya dikonversikan menjadi citra dengan format warna HSV (hue, saturation, value). Setelah kedua fitur tersebut diperoleh, dilakukan analisis terhadap 
nilai-nilainya. Akhirnya, berdasarkan nilai-nilai tersebut, ditentukan karakter dari kematangan buah kopi.

Nilai-nilai statistik dari histogram warna berupa mean, simpangan baku, skewness dan kurtosis, juga nilai-nilai momen warna diharapkan dapat memberikan karakter (ciri-ciri) dari setiap kelompok kematangan (warna) buah kopi seperti yang tertera pada Tabel 1
Tabel 1 Jumlah citra kopi dari setiap kategori

\begin{tabular}{|lr|}
\hline Jenis Citra Kopi & Jumlah \\
\hline Kopi Arabika Muda & 50 \\
Kopi Arabika Setengah masak & 50 \\
Kopi Arabika Masak & 50 \\
Kopi Arabika Tua & 50 \\
\hline
\end{tabular}

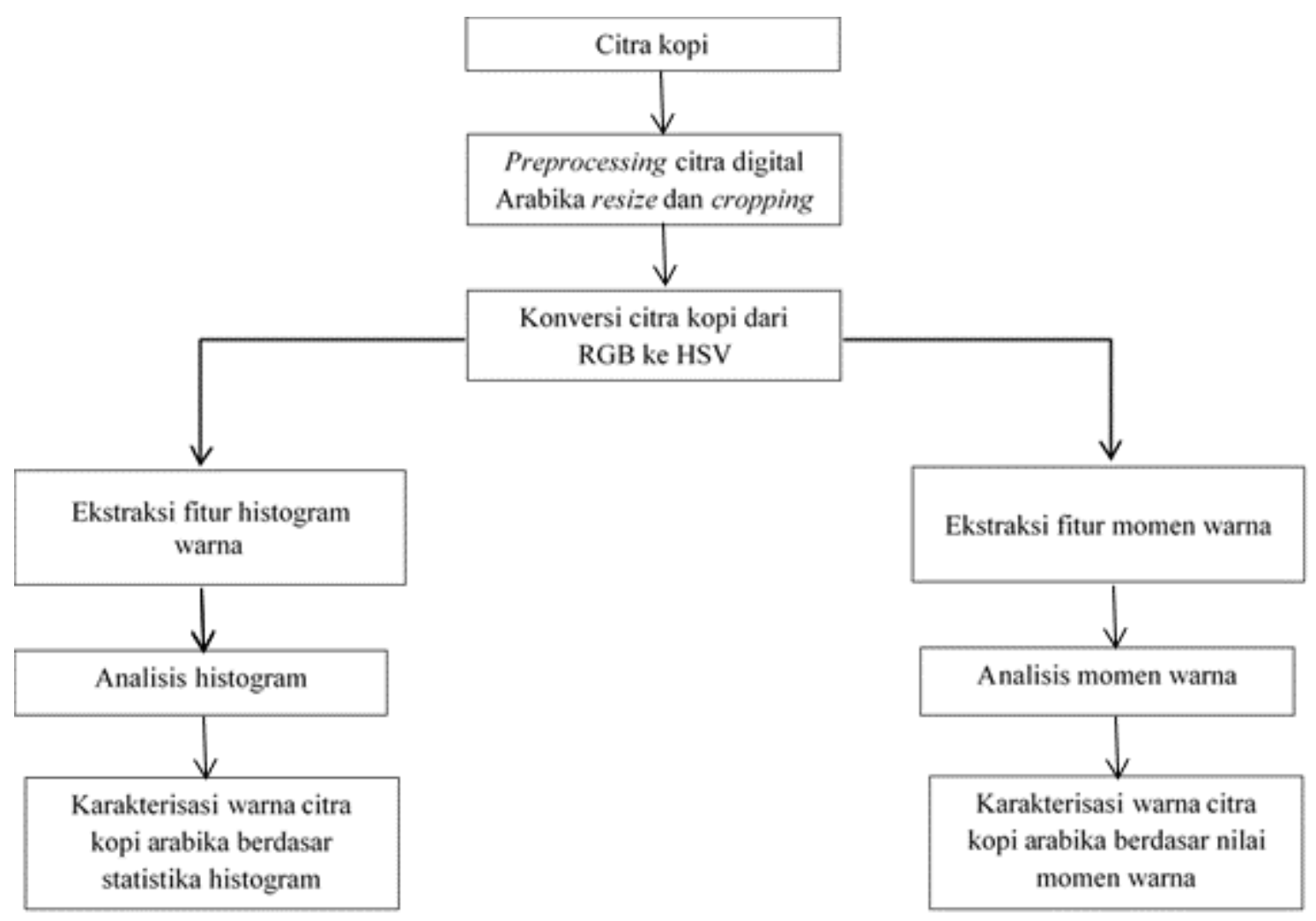

Gambar 2. Mekanisme ekstraksi histogam warna dan momen warna untuk keperluan karakterisasi warna biji kopi.

\section{Hasil dan Pembahasan}

\subsection{Pre-processing}

Tahap awal dari pre-processing ditunjukkan pada Gambar 3. Gambar 3 (a) menunjukkan proses segmentasi buah kopi pada citra. Pertama sekali, citra dikonversi menjadi citra biner. Selanjutnya, deteksi tepi dilakukan melalui operasi konvolusi dengan metode thresholding sehingga diperoleh tepi dari buah kopi yang merepresentasikan luas dari objek. Luas objek kemudian dihitung dengan cara menjumlahkan seluruh angka 1 (piksel berwarna putih) pada citra tepi yang diperoleh luas objek dihitung dalam satuan piksel. Selanjutnya operasi morfologi digunakan untuk mendapatkan boundary dari citra biner, dan hasilnya di-overlapkan dengan citra asli. Proses terakhir adalah menentukan bounding-box pada citra asli. Berdasarkan lokasi bounding-box ini, citra asli dicrop. Gambar 3(b) menunjukkan hasil cropping tersebut. Pada Gambar 4 ditunjukkan hasil konversi warna RGB ke format warna HSV dari kopi pada Gambar 3(b). 
Hendri Syahputra: Jurnal Nasional Teknik Elektro, Vol. 8, No. 1, Maret 2019

Citra Asli Kopi Arabika Muda

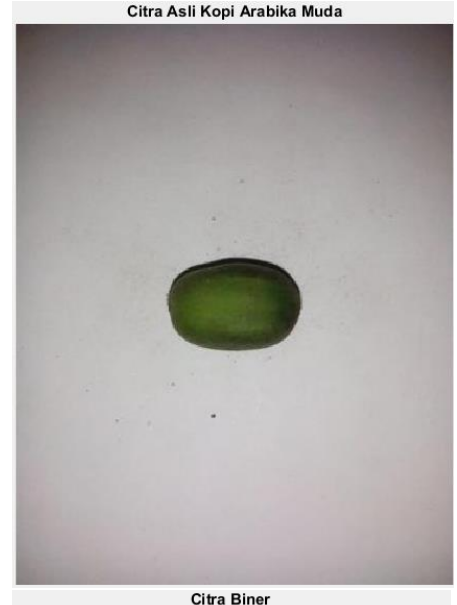

Citra Biner

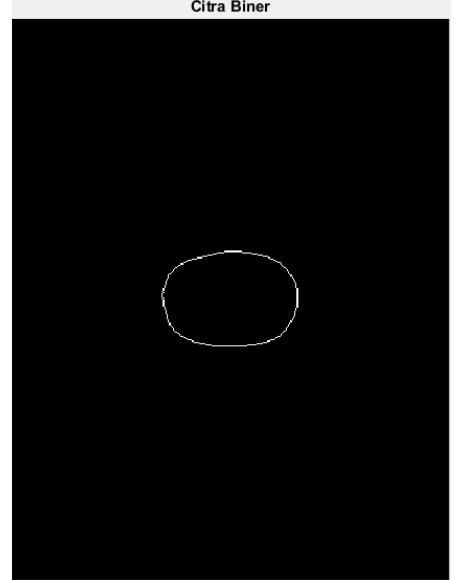

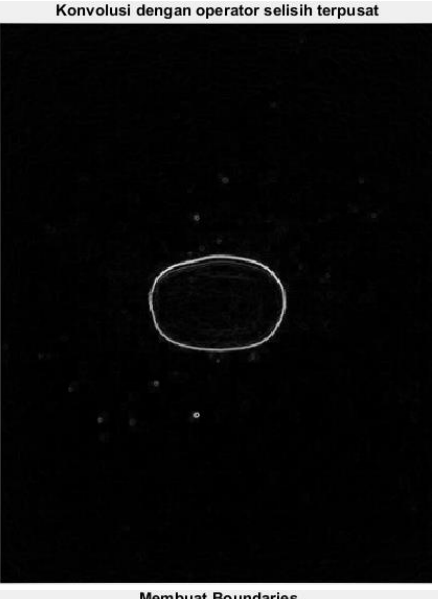

Membuat Boundaries

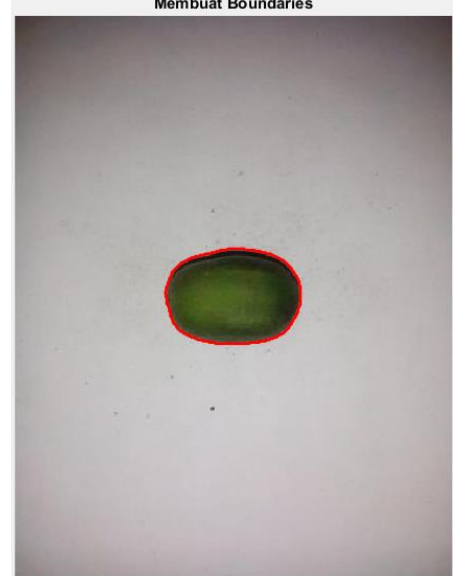

(a). Proses segmentasi untuk penentuan lokasi citra kopi

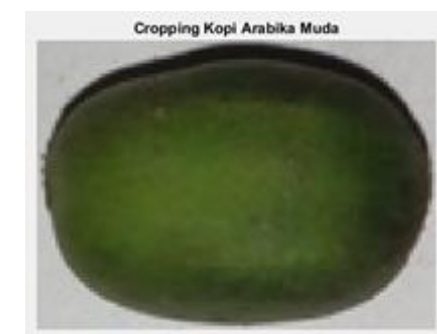

(b). Hasil cropping berdasarkan bounding box

Gambar 3. Proses cropping citra buah kopi

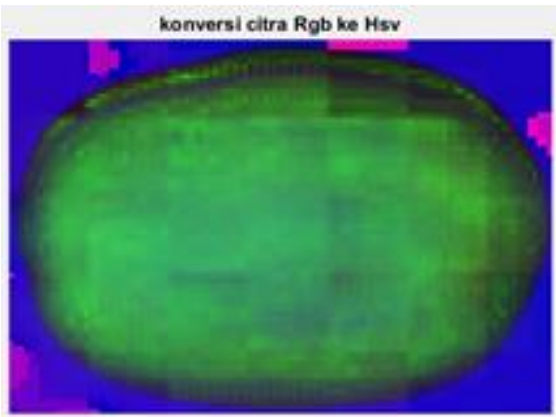

Gambar 4. Konversi nilai RGB ke HSV Kopi Arabika Muda pada Gambar 3(b) 
Gambar 5 menunjukkan histogram warna dari masing-masing komponen $\mathrm{H}, \mathrm{S}$ dan $\mathrm{V}$ dari citra kopi pada Gambar 4. Pada bagian selanjutnya ditunjukkan bahwa nilai statistik dari histogram hue dapat menentukan karakter kematangan kopi berdasarkan warna.

\subsection{Hasil Analisis histogram warna}

Hasil simulasi dari fitur histogram dari komponen HSV dari empat jenis kematangan buah kopi yaitu: kopi muda, kopi setengah masak, kopi masak, dan kopi tua ditampilkan pada Gambar 6 sampai dengan 9. Terdapat perbedaan penyebaran nilai piksel pada histogram hue dari keempat kelompok warna kopi. Histogram hue dari kopi muda dan kopi setengah masak terkonsentrasi pada sebelah kiri histogram. Histogram hue dari kopi masak terkonsentrasi pada sebelah kiri dan kanan histogram, sementara untuk kopi tua, histogram huenya berada berada pada hampir semua bagian, dengan kepadatan yang tinggi pada bagian kiri, tengah dan kanan.

Dari Gambar 6 s.d Gambar 9 juga dapat diamati penyebaran nilai piksel dari komponen saturasi. Kopi dengan warna hijau, kuning dan merah memiliki saturasi yang agak besar dengan puncak nilai saturasi berada pada 0.6 s.d 0.8 . Sementara untuk kopi tua, nilai saturasi terpusat pada nilai 0 s.d 0.5 . Selanjutnya, histogram dari value juga menunjukkan karakteristik yang berbeda dari keempat warna kopi di gambar 1

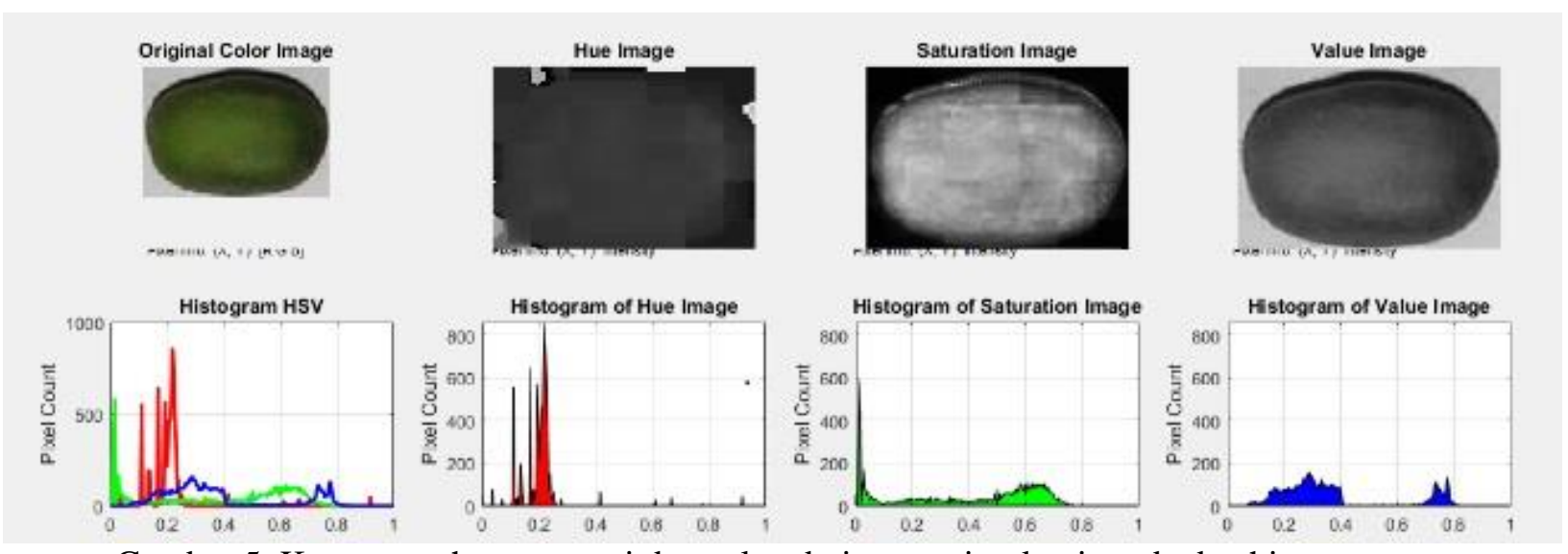

Gambar 5. Komponen hue, saturasi dan value dari suatu citra kopi muda dan histogramnya
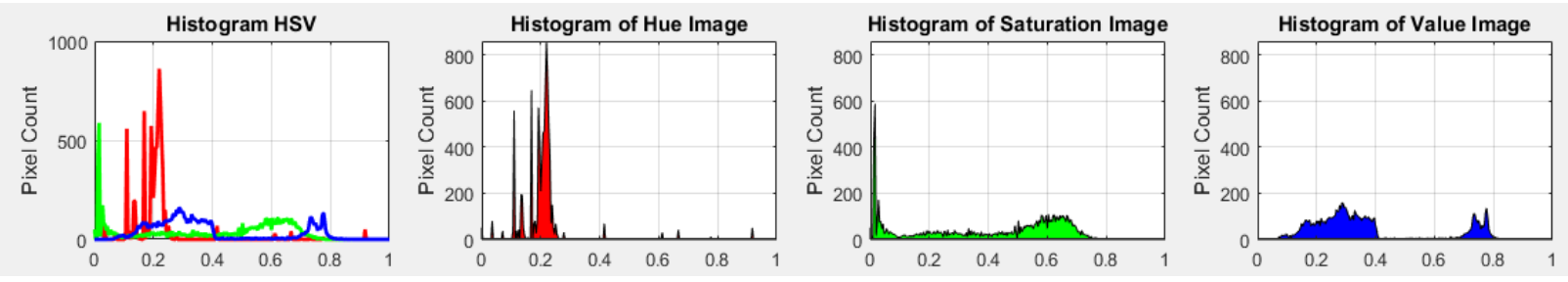

Gambar 6. Histogram warna HSV dari citra kopi arabika muda
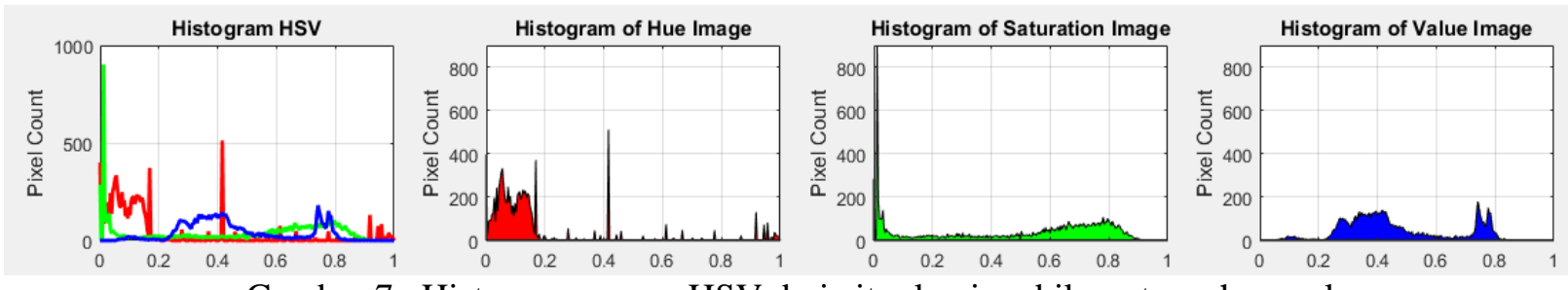

Gambar 7. Histogram warna HSV dari citra kopi arabika setengah masak 

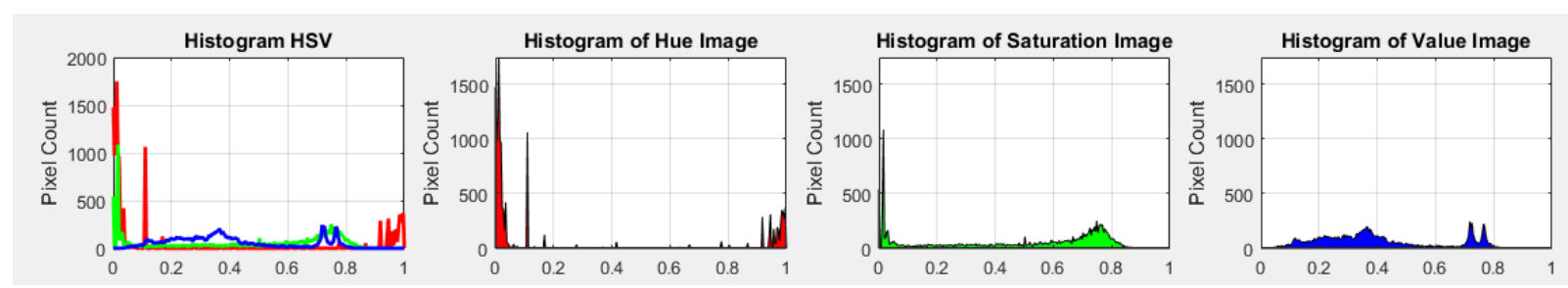

Gambar 8. Histogram warna HSV dari citra kopi arabika masak

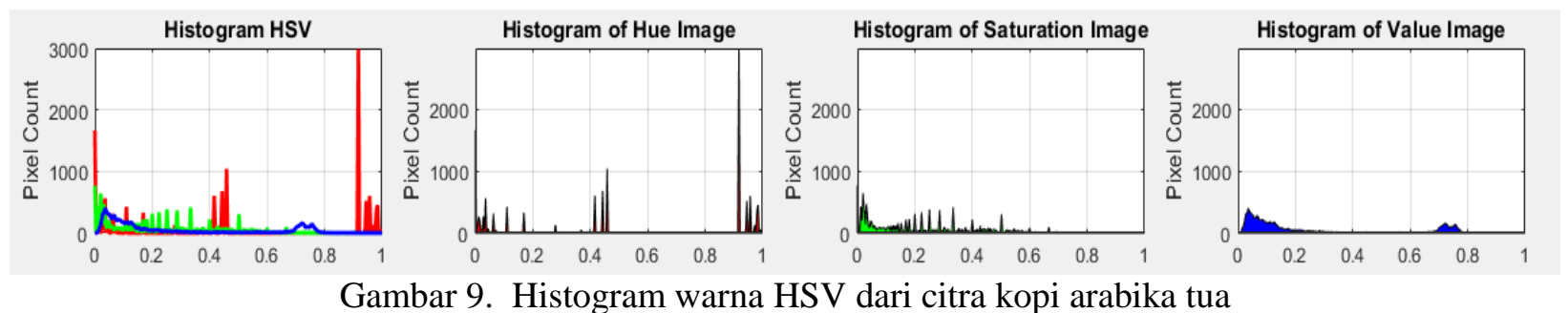

Pengamatan terhadap bentuk histogram dari $\mathrm{H}$, $\mathrm{S}$ dan $\mathrm{V}$ menunjukkan potensi untuk menggunakan nilai statistik dari histogramhistogram tersebut sebagai penciri atau penentu karakter dari warna kopi.

Jika Gambar 6 sampai dengan Gambar 9 menyajikan contoh histogram dari keempat kelompok warna (kematangan) buah kopi; Tabel 2 memberikan rentang nilai (selisih nilai minimum dan maksimum) besaran statistik histogram warna berupa mean, variance, skewness dan kurtosis dari 50 citra kopi seperti tertera pada Tabel 1. Pada Tabel 2, terdapat beberapa nilai yang tidak memiliki interval, misalnya pada kolom skewness dari nilai value dari kopi muda, yaitu 1.3.

Hal ini disebabkan interval dari nilai-nilai tesebut lebih kecil dari 0.05 (pembulatan ke nilai satu desimal menyebabkan pembulatan ke angka yang sama). Pengamatan seksama dari Tabel 2 memberikan informasi bahwa nilai mean dari HSV dan nilai kurtosis dari hue adalah yang paling bisa membedakan antara satu warna kopi dengan yang lain. Pada tabel 2, nilai-nilai ini ditulis dengan tinta tebal.

\subsection{Hasil analisis momen warna}

Hasil perhitungan nilai momen warna dari keempat kategori kopi ditunjukkan pada Tabel 3. Nilai-nilai yang tertera adalah rentang antara nilai terendah dan tertinggi dari 50 kopi untuk setiap kategori. Pengamatan terhadap data ini memberikan informasi bahwa nilai momen warna kurang sesuai untuk memberikan karakteristik warna buah kopi. Tidak ada sekelompok nilai yang bisa membedakan satu warna kopi dengan warna kopi lain.

Jika dipadankan dengan teori, seharusnya nilai momen dari komponen hue memberikan rentang nilai yang berbeda antara satu warna kopi dengan yang lain. Namun hal ini juga tidak terbukti. Komponen hue memiliki nilai momen pertama (mean) yang sama antara kopi muda dan kopi setengah masak. Selanjutnya, nilai simpangan baku (dituliskan sebagai 'std' pada Tabel 3) juga saling bertumpang tindih antara kopi masak dan kopi tua. 
Tabel 2. Besaran nilai statistik histogram dari empat kategori kematangan berdasarkan warna dari citra kopi

\begin{tabular}{|c|c|c|c|c|c|}
\hline \multicolumn{2}{|c|}{ Keadaan Kopi } & Muda & $\begin{array}{c}\text { Setengah } \\
\text { masak }\end{array}$ & Masak & Tua \\
\hline Mean & HSV & $\mathbf{3 6 . 0 - 3 9 . 4}$ & $\mathbf{4 0 . 5 - 4 2 . 0}$ & $\mathbf{4 2 . 0 - 4 3 . 0}$ & $\geq \mathbf{4 4}$ \\
\hline \multirow{4}{*}{ Variance } & $\mathrm{H}$ & $2.4-3.8$ & $3.8-4.0$ & $4.1-4.7$ & $\geq 4.7$ \\
\cline { 2 - 6 } & $\mathrm{S}$ & $3.1-3.3$ & $3.3-3.8$ & $3.8-4.8$ & $\geq 4.8$ \\
\cline { 2 - 6 } & $\mathrm{V}$ & $2.4-2.6$ & $2.6-2.7$ & $2.7-4.7$ & $\geq 4.7$ \\
\hline \multirow{4}{*}{ Skewness } & $\mathrm{H}$ & $3.0-3.5$ & $3.5-4.5$ & $5.2-7.5$ & $\geq 8.2$ \\
\cline { 2 - 7 } & $\mathrm{S}$ & $5.1-5.3$ & $5.3-5.4$ & $5.4-4.5$ & $\geq 5.8$ \\
\cline { 2 - 7 } & $\mathrm{V}$ & 1.3 & 1.3 & $1.3-1.9$ & $\geq 2.2$ \\
\hline \multirow{3}{*}{ Kurtosis } & $\mathrm{H}$ & $\mathbf{1 7 . 2 - 2 8 . 3}$ & $\mathbf{2 9 . 2 - 3 1 . 4}$ & $\mathbf{3 2 . 7 - 8 3 . 5}$ & $\geq \mathbf{8 4 . 2}$ \\
\cline { 2 - 7 } & $\mathrm{S}$ & $44.5-46$ & $46-47.4$ & $31-36$ & $\geq 55.1$ \\
\cline { 2 - 7 } & $\mathrm{V}$ & $3.5-3.9$ & $3.9-4.1$ & $4.5-7.0$ & $\geq 7.6$ \\
\hline
\end{tabular}

Tabel 3. Nilai momen dari komponen hue, saturation dan value dari empat kategori citra kopi

\begin{tabular}{|c|c|c|c|c|c|}
\hline \multicolumn{2}{|c}{} & $\begin{array}{l}\text { Kopi } \\
\text { Muda }\end{array}$ & $\begin{array}{l}\text { Kopi } \\
\text { Setengah } \\
\text { masak }\end{array}$ & $\begin{array}{l}\text { Kopi } \\
\text { Masak }\end{array}$ & Kopi Tua \\
\hline \multirow{4}{*}{ Hue } & mean & 0.2 & 0.2 & $0.2-0.4$ & $\geq 0.4$ \\
\cline { 2 - 7 } & std & $0.1-0.2$ & $0.2-0.3$ & $0.3-0.4$ & $\geq 0.3$ \\
\cline { 2 - 7 } & skewness & $2.2-2.4$ & $1.7-2.2$ & $0.4-1.8$ & $\geq 0.4$ \\
\hline \multirow{5}{*}{ Saturation } & mean & $0.4-0.5$ & 0.5 & $0.2-0.4$ & $\geq 0.2$ \\
\cline { 2 - 7 } & std & $0.2-0.3$ & 0.3 & 0.1 & $\geq 0.1$ \\
\cline { 2 - 7 } & skewness & 0.1 & 0.1 & 0.2 & $\geq 0.7$ \\
\hline \multirow{5}{*}{ Value } & mean & $0.4-0.5$ & 0.5 & $0.2-0.3$ & $\geq 0.3$ \\
\cline { 2 - 7 } & std & 0.2 & 0.2 & $0.2-0.3$ & $\geq 0.3$ \\
\cline { 2 - 7 } & skewness & $0.4-0.5$ & $0.5-0.7$ & $0.7-1.1$ & $\geq 1.1$ \\
\hline
\end{tabular}

\section{Kesimpulan}

Berdasarkan analisis nilai-nilai fitur tersebut, yang diambil dari 200 citra kopi, disimpulkan bahwa fitur warna berupa nilai statistik dari komponen hue histogram warna lebih sesuai untuk mewakili karakter kematangan berdasarkan warna dari buah kopi. Nilai kurtosis dari histogram hue memiliki nilai berbeda untuk setiap kategori kematangan buah kopi: kopi muda memiliki nilai kurtosis 17.2-28.3, kopi setengah masak 29.2-31.4, kopi masak 32.7-83.5 dan kopi tua lebih dari 84.2.

\section{Daftar Pustaka}

[1] P. Rahardjo, "Kopi Panduan Budidaya dan Pengolahan Kopi Arabika dan Robusta," Jakarta: Penerbit Penebar Swadaya, 2012.

[2] A.S, Somantri, "Teknologi pengolahan citra digital untuk identifikasi mutu fisik produk tanaman perkebunan," Warta Penelitian dan Pengembangan Tanaman Industri, Pusat Penelitian dan Pengembangan Perkebunan, 2009.

[3] B. M. Ayitenfsu, "Method of Coffee Bean Defect Detection," International Journal of Engineering Research \& Technology (IJERT), vol. 3, no. 2, pp. 2355-2357, Feb, 2014. 
[4] F. Faridah, G. O. F. Parikesit, F. Ferdiansjah "Coffee Bean Grade Determination Based on Image Parameter," TELKOMNIKA, vol.9, no.3, pp. 547-554, Dec, 2011.

[5] B. Turi, G. Abebe, G. Goro, "Classification of Ethiopian Coffee Beans Using Imaging Techniques," East African Journal of Sciences, vol. 7, no. 1, pp. 110, Jan, 2013.

[6] E. Carrillo dan A. A. Peñaloza, "Artificial Vision to assure Coffee-Excelso Beans quality," The 2009 Euro American Conference on Telematics and Information Systems: New Opportunities to increase Digital Citizenship, Prague, 2009.

[7] R. Calvini, A. Ulrici, J. Amigo, "Practical comparison of sparse methods for classification of Arabica and Robusta coffee species using near Infra-red hyperspectral imaging," Chemometrics and Intelligent Laboratory Systems, vol. 146, pp. 503-511, Aug, 2015.

[8] E. M. Oliveira, et.al, "A computer vision system for coffee beans classification based on computational intelligence techniques," Journal of Food engineering, vol 171, pp. 22-27, Feb, 2016.
[9] J. C. Caban. (2010, Sep.). Introduction to Image Statistics. [Online]. Available https://www.csee.umbc.edu/ caban 1/Fall2 010/CMSC691//Schedule_files/Docs/08ImageStatistics.pdf

[10] N. Keen, "Color Moments," unpublished.

\section{Biodata Penulis}

Hendri Syahputra, Menyelesaikan pendidikan S2 pada jurusan Magister Teknik Elektro Universitas Syiah Kuala tahun 2018 dibidang Pengolahan Citra.

Fitri Arnia, Menyelesaikan pendidikan S1 pada jurusan Teknik Elektro Universitas Sumatera Utara. Studi S2 di University of New South Wales, Australia. Gelar Doktor diperolehnya dari Tokyo Metropolitan University, Jepang dengan kajian pengolahan citra.

Khairul Munadi, menyelesaikan pendidikan S1nya di jurusan Teknik Elektro, Institut Teknologi Sepuluh Nopember, Surabaya. Pendidikan S2 dan S3 diselesikan di Tokyo Metropolitan University, Jepang. Bidang penelitian yaitu multimedia, pengolahan citra dan penanggulangan bencana. 